\title{
A szociális kompetencia érzelmi elemeinek fejlesztése zeneterápiás eszközökkel tanár szakos hallgatók körében
}

Vizsgálatunk célja zeneterápiás eszközökkel végzett tréningprogram kidolgozása és kipróbálása volt, amely fejleszti a tanárképzésben részt vevố hallgatók szociális kompetenciájának érzelmi elemeit. Fejlesztố programunkban szociáliskészség-fejlesztố technikákat alkalmaztunk, kiegészitve azokat a zeneterápiában használt módszerekkel és eszközökkel. A gyakorlatok végzése során a hallgatók megtapasztalták a módszerek hatását, így a késóbbiekben képesek lesznek azokat osztálykeretben alkalmazni. Vértes (2010) eredményei alapján feltételeztük, hogy a zeneterápiás eszközöket alkalmazó technikák közvetett hatásaként megjelenik a zenei viszony elmélyülése is. Jelen tanulmány a tréning eredményeit ismerteti.

\section{A fejlesztés igénye és a pedagógiai kerete}

A zeneterápiás eszközökkel végzett fejlesztés fontosságát alátámasztja, hogy a mai kor embere egyre inkább szembesül a természetes, társadalmi támogató rendszerek ('social supporting network') meggyengülésével (pl. Seeman, Kaplan, Knudsen, Cohen és Guralnik, 1987; Gerevich, 1997). A rendszer mindazon kötődéseinket és társas kapcsolati hálónkat tartalmazza, ami segít a személyes és szakmai integritás fenntartásában és ápolásában. A probléma az, hogy a megnevezett rendszer önmagában ugyan szervezett, viszont kapcsolatuk és a közöttük lévő átjárás nehézkes. Elégtelen a róla szóló információáramlás. A számukra nyújtott keret- és feltételrendszer pedig céljaiknak és müködésüknek nem megfelelö.

A pedagógiai gyakorlatban a probléma úgy nyilvánul meg, hogy a ma tanára szembekerül avval, hogy a nevelöi munka nem tudja normaképző és normát számon kérö funkcióját betölteni, mert az oktatás-nevelés folyamata akadályozott a gyermekek kívülröl jövő nehézségeivel, amit a pedagógusnak az osztálykeretben kellene megoldania. Ehhez a gyakorlati helyzethez társul az oktatáspolitika (ld. NAT, 2012) és a társadalom elvárása például a kompetenciafejlesztés, az integrációs törekvések mentén. A megnevezett feladatokhoz pedig hiányos az oktatóknak nyújtott cél-, keret-, feltétel- és eszközrendszer. A tanárképzésben részt vevő hallgatók fejlesztésének igénye a hazai hiányosságokból fakad. A fejlesztő programok szükségességét alátámasztja az is, hogy ha osztályszintü fejlesztést várunk a pedagógusoktól, akkor először az érintettek fejlesztését kell elkezdeni. Mégpedig olyan módon, hogy már a képzésük során tapasztalatot, módszert és eszközrendszert biztosítunk ehhez. Mindehhez a leghatékonyabb keret egy saját élményü fejlesztő tréningprogram lehet. 


\section{Fejlesztési irányok és módszerek}

A fent nevezett hiányosságokból és elvárásokból kitünik, hogy az eredményes társas viselkedést lehetővé tevő pszichikus feltételrendszer, vagyis a szociális kompetencia fejlesztése a legégetőbb. Az elméleti háttér alapján elmondhatjuk, hogy a szociális kompetenciát fejlesztő irányzatok követik a szociális kompetencia modellezésének irányát. A '70-es években a megfigyelhető viselkedés, a '80-as években a gondolkodási folyamatok és a ' 80 -as évek végén az érzelmek viselkedésbeli szerepe állt a fejlesztési irányok középpontjában. Habár a '80-as évek végétől megjelentek a komplexitásra törekvő fejlesztési modellek, a programok ma is inkább a megfigyelhető viselkedésre fókuszálnak (Kasik, 2007).

A tréningek céljait tekintve ugyancsak párhuzam állítható fel a modellek elméleti fókusza és a fejlesztési célok között. A '70-es években a szociális készségek tanítása, a '80-as években az osztályszintü preventív fejlesztés, a '90-es években pedig a tartalomba ágyazott vagy pedig a direkt fejlesztés állt a középpontban. A (1) viselkedésváltozás kognitív elmélete a kognitív folyamatok viselkedésben játszott szerepét hangsúlyozza. A (2) fejlesztő programok ebben az esetben a szociális probléma megoldását célozzák. A (3) humanisztikus szemléletet és az érzelmek viselkedésalakító szerepét hangsúlyozó programok középpontjában az empátia, a pozitív társas kapcsolatok alakítása, illetve az elfogadás áll. A (4) behaviorista nézőpontú fejlesztések az érzelmek leírásán és értelmezésén, a viselkedésrepertoár gazdagításán alapulnak. Az integratív fejlesztési megközelítésben komplex programokkal találkozhatunk.

A direkt fejlesztésben két irányt különböztetünk meg. Az egyikben például adott szociális készségek fejlesztése folyik beszélgetés, szerepjáték, helyes viselkedés begyakorlása által. A másikban a társas interakciók problémáinak hatékony megoldása áll a központban, például különböző szituációs gyakorlatok segítségével. Az indirekt fejlesztés szerint pedig egy-egy tantárgyhoz vagy tananyaghoz kapcsolódóan végezzük a gyakorlatokat, például szövegek elemzésével és dramatikus feldolgozásának segítségével (Kasik, 2012).

A fejlesztési anyag kiválasztásánál kulcskérdés a gyakorlat okozta kihívás, nehézség megfelelő szintjének kitüzése, amivel a siker- és kompetencia-, valamint a pozitív self-érzet kialakulásához járulhatunk hozzá. Han és Kemple (2006) szerint a támogató (szupportív) fejlesztési stratégiák hierarchikus rendszert alkotnak, és fejlesztésre az osztálytermi környezetet javasolják. A tanterem elrendezése, hatékony manipulálása a szociális készségek támogatását teszi lehetővé. Kis csoportok kialakításával könnyen szabályozhatjuk a kijelölt szociális területet például dramatikus játékokkal. Egy „,privát tér" kialakítása (pl. sátor, babzsák), ahová a gyermek elvonulhat, a pozitív önszabályozást és a frusztrációval való megbirkózást segíti elő.

Rendszerükben a naturalisztikus stratégiák a tantermi interakciók természetes áramlásának tanári irányítását, a helyszíni támogatást ('on the spot'), a megerősítést, a konfliktus-mediációt és a rutintevékenységek tervezését foglalják magukba. Példájuk szerint a helyszíni támogatással a szociális tudás, önszabályozás, érzelemkifejezés területeire lehet hatni. Például egy rajzolás alkalmával a tanár jelezheti a gyermek felé azt, amit érzékel a képről, és így a gyermek hallja és fiziológiailag is átéli azt az érzelmet, amit a kép kifejez. A megerősítés növeli egy megfelelő viselkedésforma megismétlésének valószínűségét. Lehet az például egy szóbeli dicséret, jutalom-matrica, mosoly, átölelés. Megjelenhet például öszinteség, felelősség, alkalmazkodás megnyilvánulása esetén. Hangsúlyoznunk kell, hogy csak akkor hatékony a jutalom, ha formája egyéni és egyedi. Növeli a mások iránti érzékenységet, kooperációt, pozitív self-érzetet, tervezést és döntéshozatalt.

A konfliktus-feldolgozás keretében a vitás kérdés agresszió és vita nélküli megoldása történik. A konfliktus megoldása a probléma azonosításától, alternatív megoldásmódok kidolgozásán és elfogadásán át a megoldás értékeléséig több lépcsőn keresztül törté- 
nik. Segítik az interperszonális készségek fejlődését, mint például az együttműködést, a kompromisszumkészséget, mások jogainak elismerését vagy az érzések, ötletek, igények kommunikálását. A rutintevékenységek tervezésénél figyelni kell, hogy maximalizáljuk annak lehetőségét, hogy a tanuló elérje célját. Egy, a csoport által kedvelt tevékenység, mint a közös éneklés, segíti az érzelmek kifejezését, a barátságok kötését, a másik elfogadását, a kontaktusteremtést.

A magas intenzitású intervenciók tervezésénél szándékos viselkedés-befolyásolás történik direkt instrukciók által. Azokban az esetekben alkalmazzuk, ahol a kevésbé intenzív technikák nem vezettek eredményre. A megnevezett technikát alkalmazó pedagógusnak pedig rendelkeznie kell a viselkedésanalízis, a megerősítés hatékony alkalmazásának képesítésével. Az intervenciókat moderálhatja a pedagógus vagy akár egy társ is.

Gyakorlati példa Greca és Santogossi (1980) tréningprogramja, ami az illedelmes köszönést, a csoporthoz való csatlakozást, az osztozkodást, a kooperációt és tiszteletadás gyakorlását tüzte ki célul. Ezek feldolgozása modellezésből, helyzetek kipróbálásából és begyakorlásából állt, melyet megfigyelők különböző értékelési szempontrendszer szerint osztályoztak. Denham és Burton (1996) a szociális és érzelmi fejlesztő tréningjüket óvodások körében végezték. A gyakorlatok kivitelezésére az előre felkészített nevelők a kapcsolatépítéshez, az érzelmek megértéséhez és a szociális probléma megoldásához kapcsolódó intervenciókat fejlesztettek ki. A fejlődést megfigyelésen és tanári kérdőíven keresztül értékelték, összehasonlítva olyan csoporttal, akik nem vettek részt a programon. Tréningük nyomán csökkent a negatív érzelmek kifejezésének száma, és több pozitív páros aktivitást figyeltek meg. Nézetük szerint összességében a tanárok által végzett programmal sikerült fejleszteni a gyerekek szocialitását.

Cheung és Lee (2010) középiskolások között alkalmazott jellemépítési programmal hozzájárultak a szociális kompetencia fejlődéséhez. Felhívják a figyelmet arra, hogy a program szerkezetét, felépítését és elemzését mindvégig meghatározta a részvételi hajlandóság. Elemzésük szerint a fejlődés hatásmértékében nagy szerepet kapott a program melletti elköteleződés és a szociális kompetencia programot megelőzően alacsony szintje.

Konta (2010) szerint a fejlesztő technikákhoz zeneszerszámokat és bárki által végrehajtható zenei gyakorlatokat rendelhetünk. Ezek növelik a technikák hatását, hitelesebbé teszik a kommunikációt, az átélt élményt, és szélesebb tapasztalati mezőt biztosítanak, valamint megadják a foglalkozások keretét. Le kell szögeznünk, hogy az alkalmazott zeneterápiás eszközök sehol, semmilyen formában nem helyettesítenek más önálló eljárásokat, hanem azok egy alaptevékenység kiegészítő elemei. Az alaptevékenységet a fejlesztést végző pedagógus eredeti professziója határozza meg.

A programok példáiból kitünik, hogy azok leginkább a kisgyermekek és a serdülők korosztályára fókuszálnak. Hiányzik a fejlesztést végzők tréningje.

\section{Az érzelmi tényezők és a zenei elemek elméleti háttere}

Az elméleti hátteret tekintve elmondható, az 1980-as években megjelentek azok a szociáliskompetencia- rendszerek, amelyek kiemelik az érzelmek meghatározó szerepét a társas viselkedésben. Viszont az érzelmi tényezők hangsúlyozása a szociális kompetencia modellezésében csak a '90-es években kezdődött el. A kutatók többsége ettől kezdve úgy véli, hogy az érzelmeknek és a gondolkodási folyamatoknak egyaránt fontos szerepe van a társas viselkedés szabályozásában (Zsolnai, 2010). Az érzelmi elemeket önálló kompetenciaként kezelő Saarni (1999, 2001) az érzelmi kompetenciát főként az énhatékonyság müködésének keretében értelmezi, melynek elemei érzelmeket előhívó szociális helyzetekben jelennek meg. Alapvető komponensei a saját érzelmi állapot tudatossága, a mások 
érzelmeinek felismerése, a másik fél érzelmi állapotának megértése és az érzelmeink megfelelő kommunikálása.

Denham, Blair, DeMulder, Levitas, Sawyer, Auerbach-Major és Queenan (2003) felfogásában ugyancsak azt találjuk, hogy az érzelmek kifejezése az első meghatározó komponense az érzelmi kompetenciának. Példájuk szerint míg a pozitív érzelmek kifejezése elösegítheti a baráti kapcsolatok kialakítását, addig a negatív érzelem kifejezése akadálya lehet mindennek. Rendszerükben az érzelmek pontos megértése több proszociális választ feltételez, és így az egyént szociálisan kompetensebbnek ítélhetik. Az érzelmek ismerete a második fontos tényezője az érzelemi kompetenciának. Segít megfelelően reagálni a másik viselkedésére, aminek segítségével a kapcsolat jobban érthetővé válik. Ezért a szerzők összefüggésbe hozzák érzelmeink ismeretét, azok kifejezését, a proszocialitást és a szociometriai státuszt. Az érzelmek szabályozása az érzelmi kompetencia harmadik fontos eleme. Ha az érzelmek kifejezése, azok megtapasztalásának intenzitása, és ennek időtartama vagy egyéb paramétere túl megterhelő vagy éppen túlságosan kevés, akkor az érzelmek megfelelő szabályozására van szükség. Megközelítésükben az érzelmi és a szociális kompetencia nagymértékben összefügg, azonban egymástól elkülöníthető rendszer.

Blair, Denham, Kochanoff és Whipple (2004) szerint az érzelemszabályozás központi szerepet kap a szociális interakciók sikerességében. Az előbbiekhez hasonló példájukban érzelmeink irányítása és szabályozása elősegíti a társas kapcsolatok kialakítását és fenntartását. Például egy stresszel terhelt helyzetben a megfelelő szabályozás segítségével ne csak a saját negatív érzéseinket értékeljük, hanem vegyük figyelembe annak a másik érzéseivel való kapcsolatát is. Továbbá szerintük az érzelem szabályozása összefügghet a megfelelő szociális viselkedéssel, a társak közti népszerüséggel, az alkalmazkodással és a félénkséggel. Visszajelzést adhatnak olyan komplex folyamatokról, amelyek az érzelemkifejezés mögött állnak. Azaz segítenek megérteni azt, hogyan és miért keletkeznek érzelmeink. Ugyanakkor gátolhatják a következő folyamatokat, mint a figyelmi fókusz, a problémamegoldás vagy a kapcsolatépítés. A szerzők rendszerében az érzelemszabályozás összefüggésben áll olyan meghatározó személyiségvonással, mint a temperamentum, minthogy az az érzelemszabályozás fejlődési folyamatát befolyásolja; és e kettőnek korai párhuzamos felmérése a későbbi beállítódásunkat komplexebben elöre jelezheti. Ezen kívül a temperamentum és érzelemszabályozás kapcsolatának közös értékelése mutatója lehet a szociális funkciók olyan aspektusainak, mint például a proszociális viselkedés, a társak közti elfogadottság és a beállítódás.

Gross (2003) megközelítése az érzelemszabályozás két formáját hangsúlyozza a szociális kompetencia rendszerén belül. Az egyik az újraértékelés, ami a helyzet azonnali értelmezésére vonatkozik, mérsékelve ezzel az adott szituáció érzelmi hatását. Ez csökkenti az érzelmi állapotot és annak viselkedésbeli kifejezését, viszont a későbbi emlékképre nincsen hatása. A másik az elnyomás, ami az érzelmet generáló folyamatban később jelentkezik, mérsékelve a belső állapot külsőleg is megnyilvánuló jegyeit. Az elnyomás ugyan csökkenti a viselkedésbeli kifejezést, de nem mérsékli az érzelmi tapasztalatokat, és az emlékképre is eröteljes befolyással bír. Ezen kívül növeli a fiziológiai reakciókat mind az elnyomóban, mind annak szociális partnereiben. A fenti vizsgálatokból kiderül, hogy az érzelmi tényezők mennyi egyéb, a személyiség aktivitását befolyásoló területtel függenek össze. Együttes, harmonikus müködésük és normál ütemben történő fejlődésük meghatározó lehet a későbbi szociális sikerességünkre nézve is. Éppen ezért elengedhetetlen a tréningprogramok kidolgozása és beépítése az oktatás-nevelés folyamatába.

Zsolnai és Józsa (2003) szerint komplexebb hatást tudunk elérni a fejlesztés során, ha az egyes készségfejlesztő technikákat kiegészítjük zenei elemekkel. Fontos, hogy a választott eszközök formája, használata, hangja felkeltse, ne pedig elterelje a fejlesztésben részt vevők figyelmét a szóban forgó gyakorlatról. Szükséges, hogy felkeltsék a figyelmet, serkentsék az ötletességet, és különféle megoldási módokat kínáljanak fel. 
A feladatok és a zenei elemek összekapcsolása komplexebb megnyilvánulási és önkifejezési lehetőséget kínál. Egyedüli „szerepléstől” a közösségi aktivitáson át az alkotói tevékenységig számtalan önkifejezési mód szerepel a repertoárban. A zene jelen esetben nem cél, hanem eszköz, mely kiegészítő elemként egyaránt szolgálja a megelözést és fejlesztést, a gyógyítást és a rehabilitációt. Megjegyezzük, hogy a pedagógiai megközelítésben az előbbi felsorolásból az első funkció az érvényes és használatos.

Konta (2010) szerint a zene közvetítő, katalizátor funkciót tölt be. Segíti az átélt élmény elmélyülését. Abból indul ki, hogy a motiváló eszközök, a ráhangoló érzelmek fokozzák a gyakorlatok hatását és eredményességét. Ennek mértékét megnöveli, ha az átélt élményhez zenei tapasztalat is társul. A zene preverbális szinten hat, nem állít intellektuális követelményeket. A programok során nem a jó és rossz kategóriák érvényesülnek, hanem a kísérletezés, a jókedv, a hatások észlelése, értelmezése, tudatosítása. A résztvevő az események alkotója, részese, így a különböző helyzetek között összefüggéseket teremthet tapasztalásai által. Így az mondhatjuk, hogy az alkotás közös élményén keresztül integrálható a zene a szociális készségek fejlesztésébe. A zeneterápia tehát Konta és Zsolnai (2002) alapján egy olyan módszer, amelyben a zenét mint eszközt használjuk egy komplex eljárás részeként a megelőzés, a személyiségfejlesztés, a korrekció, a gyógyítás, a rehabilitáció és a hospice területén egyaránt.

A zenei háttértudást jelentő területek közül legfontosabbak a zene hatásának neurológiai vizsgálata és a zene transzferhatásának jelensége. Parbery-Clark, Skoe és Kraus (2009) analóg folyamatként értelmezik a professzionális zenészek háttérdallam-elemzését és a zajban történt beszédpercepciót. Kísérletükben a zenei élmény hatását vizsgálták az idegi válaszmintázatra. Összevetették a beszédre adott subcorticális neurofiziológiai válaszokat csöndben és zajban, tréningezett zenészek és nem zenészek csoportjánál. Neurológiai mérésük eredménye szerint a professzionális zenészek gyorsabb és pontosabb idegi választ adtak zaj jelenlétében. A szerzők szerint biológiai bizonyítékot szolgáltattak a zenészek észlelési előnyére a zajban történt beszédpercepcióra vonatkozóan. Shahin, Roberts és Trainor (2004) az idegi mátrix formálhatóságára szolgáltattak bizonyítékot speciális hallási tapasztalattal. A legmagasabb fokú hallási érzékenységet a Suzuki módszerrel tréningezett hegedüs diákoknál tapasztalták, szemben a zongorista és formális képzésben részt nem vett, csupán - megfogalmazásuk szerint - tiszta zenei hanggal tréningezett diákokkal. Eredményük szerint a hegedülni tanult diákok voltak a hallásilag legérzékenyebbek. Náluk volt legmagasabb szinten kimutatható az idegsejt-hálózat komplexitása, tehát vizsgálatuk egyben a neves Suzuki zenepedagógiai módszer eredményességét is igazolta a neurális hálózat formálhatóságára vonatkozóan. Wong, Skoe, Russo, Dees és Kraus (2007) neurológiai vizsgálatában a zenei élmény formáló hatását vizsgálták az agytörzsi hálózatra vonatkozóan. Abból a feltevésből indultak ki, hogy a zene érzékelése és a beszéd egyaránt kognitív müködést igénybevevő funkció, ami inkább az agykéreg területéhez kapcsolt, mint a kéreg alatti területekhez. A nyelvi lejtés mintázatát kódoltatták zenészek és nem zenészek csoportjával. Eredményeik szerint a zenész csoport pontosabb, megbízhatóbb megfejtést adott, szemben a másik csoporttal. Ezek az eredmények nem csupán a kérgi hálózatban mutathatóak ki, hanem a kéreg alatti tartományban is hatnak a két funkcióra (zenére és beszédre), és így valószínüsíthető, hogy az agyi plaszticitásra is hatással vannak.

Összességében elmondhatjuk, hogy a fentiekben bemutatott bizonyítékok egy zeneterapeuta háttértudásában vannak jelen. Munkáját ennek fényében végzi, abban a keretben és avval a módszertani repertoárral, amit eredeti professziója diktál. 


\section{Az empirikus vizsgálat}

\section{A vizsgálat célja}

Az érzelmi elemek tekintetében célunk a fejlesztő kísérlet eredményeként a kreatív válaszok eloszlásának százalékos arányában történt szignifikáns, nagyobb mértékü változás kimutatása a kísérleti csoportokban, függetlenül a zenei professziótól.

Közvetett eredményként pedig a legelmélyültebb zenei viszonyulást jelző válaszok eloszlásának százalékos arányában történt szignifikáns, nagyobb mértékü változás kimutatása a kísérleti csoportokban, függetlenül a zenei irányultságtól.

\section{Minta}

A fejlesztő kísérletet az ELTE- Tanítóképző Karán végeztük. A mintát (N=120) 1-3. évfolyamon tanuló, tanárképzésben részt vevő hallgatók alkották. A fejlesztés hatásának vizsgálatára kontrollcsoportos kísérleti elrendezést alkalmaztunk. A kísérleti csoportba 46, a kontrollcsoportba 74 tanuló járt. A mintába önkéntes jelentkezés alapján kerültek a hallgatók. A zenész részmintát zenei előképzettséggel rendelkező, ének-zene szakon és zenei mủveltségterületen tanuló hallgatók alkották. A reál részmintát természettudományi szakon tanuló és természetismeret, informatika, matematika, környezeti nevelés specializációjú és müveltségterületes hallgatók alkották. A kísérleti és kontrollcsoportot - ugyanazon szakon, specializáción, müveltségterületen és évfolyamon tanulók közül - az elömérésen elért eredmények alapján illesztettük, mely egyben az azonos indulószintet biztosította. A kísérleti és kontrollcsoportok összevethetőek, minthogy a válaszadás eloszlása nem függött attól, hogy a hallgató a kísérleti vagy a kontrollcsoportokba járt ( $\mathrm{p}>0,05$ minden elem esetében, ld. 2-3. táblázat). Tehát az érzelmi tényezőket és a zenei viszonyulást tekintve ekvivalensnek tekinthetőek a csoportok. A megelőző tréningtapasztalatok megléte mint a mintába való bekerülés kizáró indoka alapján senkit nem kellett kihagynunk a mintából.

A minta nem, évfolyam és részminta szerinti jellemzőit az 1. táblázat tartalmazza.

1. táblázat. A fejlesztö kisérlet mintájának nem, évfolyam és szakirány szerinti megoszlása

\begin{tabular}{|c|c|c|c|c|}
\hline & \multicolumn{2}{|c|}{ Kisérleti } & \multicolumn{2}{|c|}{ Kontroll } \\
\hline Nem & 6 Férfi & 40 Nő & 8 Férfi & 66 Nö \\
\hline Évfolyam & \multicolumn{2}{|c|}{$\begin{array}{l}18-1 . \text { évfolyam } \\
16-2 . \text { évfolyam } \\
12-3 . \text { évfolyam }\end{array}$} & \multicolumn{2}{|c|}{$\begin{array}{l}28-1 . \text { évfolyam } \\
25-2 . \text { évfolyam } \\
21-3 . \text { évfolyam }\end{array}$} \\
\hline Részminta & \multicolumn{2}{|c|}{$\begin{array}{l}24 \text { zenei } \\
22 \text { reál }\end{array}$} & \multicolumn{2}{|c|}{$\begin{array}{l}37 \text { zenei } \\
37 \text { reál }\end{array}$} \\
\hline
\end{tabular}

2. táblázat. Csoportekvivalencia az érzelmi tényezők esetén $\left(\chi^{2}\right)$

\begin{tabular}{|l|c|c|c|c|c|c|}
\hline & \multicolumn{2}{|c|}{ Küldés } & \multicolumn{2}{c|}{ Fogadás } & \multicolumn{2}{c|}{ Megtapasztalás } \\
\hline Elemek & $\chi^{2}$ & $\mathrm{p}$ & $\chi^{2}$ & $\mathrm{p}$ & $\chi^{2}$ & $\mathrm{p}$ \\
\hline Tudatosság & 0,045 & 0,997 & 0,012 & 1,00 & 0,104 & 0,991 \\
\hline Azonosítás & 0,024 & 0,999 & 0,079 & 0,994 & 0,087 & 0,993 \\
\hline Kontextus & 0,012 & 1,00 & 0,087 & 0,993 & 0,079 & 0,994 \\
\hline Irányítás & 0,016 & 0,999 & 0,087 & 0,993 & 0,045 & 0,997 \\
\hline
\end{tabular}




\begin{tabular}{|c|c|c|c|c|c|c|c|c|c|c|c|}
\hline \multicolumn{12}{|c|}{ 3. táblázat. Csoportekvivalencia a zenei viszonyulás esetén $\left(\chi^{2}\right)$} \\
\hline & \multicolumn{2}{|c|}{ Intenzitás } & \multirow[b]{2}{*}{ Elemek } & \multicolumn{2}{|c|}{ Aktivitás } & \multirow[b]{2}{*}{ Elemek } & \multicolumn{2}{|c|}{ Zenei élmény } & \multirow[b]{2}{*}{ Elemek } & \multicolumn{2}{|c|}{$\begin{array}{c}\text { Környezö } \\
\text { hangzásvilág }\end{array}$} \\
\hline Elemek & $\chi^{2}$ & $\mathrm{p}$ & & $x^{2}$ & $\mathrm{p}$ & & $\chi^{2}$ & $\mathrm{p}$ & & $\chi^{2}$ & $\mathrm{p}$ \\
\hline Szükségesség & 0,104 & 0,991 & $\begin{array}{l}\text { Szere- } \\
\text { tete }\end{array}$ & 0,104 & 0,991 & Kifejezés & 0,104 & 0,991 & Észlelés & 1,30 & 1,00 \\
\hline Tudatosság & 0,024 & 0,991 & Szokása & 0,107 & 0,991 & Katarzis & 0,070 & 0,995 & $\begin{array}{l}\text { Közömbös- } \\
\text { ség }\end{array}$ & 1,30 & 1,00 \\
\hline Választás & 0,024 & 0,991 & Tudása & 0,104 & 0,991 & $\begin{array}{l}\text { Negatív } \\
\text { hatás }\end{array}$ & 0,070 & 0,995 & Zavarás & 0,87 & 0,993 \\
\hline Hiány foka & 0,087 & 0,993 & Módja & 0,903 & 0,999 & Szintek & 0,104 & 0,991 & Szeretet & 0,87 & 0,993 \\
\hline Mennyiség & 0,087 & 0,993 & Alkalma & 1,02 & 1,00 & & & & & & \\
\hline
\end{tabular}

\section{Adatfelvétel}

Előmérésre a 2015/16-os tanévben a fejlesztő program előtt, utómérésre pedig a fejlesztés után került sor. A program a tanév folyamán 24 órában zajlott csoportosan, külön tréningezve a zenei, valamint a reál csoport hallgatóit. A tréning 6 alkalomból állt, és egy-egy alkalom 4 órát vett igénybe. A korábbi tréningtapasztalatok kizáró kritériuma senkit nem érintett. A fejlesztést professzionálisan képzett zeneterapeuta vezette, aki

\section{Programunkban a szociális} kompetencia érzelmi tényezóinek fejlesztését céloztuk meg olyan gyakorlatokkal, amelyek segitik az érzelmek kifejezését, felismerését és szabályozását. A tréning indulása elótt kiválasztásra kerültek a kisérleti és kontrollcsoportok, majd utána felmértük a hallgatók érzelmi készségeinek fejlettségi szintjeit. Ezt követték a fejlesztố órák. A tréning alkalmain a szociális készségek fejlesztése során szokásosan használt technikákat alkalmaztuk: helyzetek, történetek dramatikus feldolgozása, modellnyújtás, szerepjáték, problémamegoldás, megerốsítés.

megadják a foglalkozások keretét, színesebb és hitelesebb kommunikációs csatornákat kínálnak, valamint szélesebb tapasztalatmező megélését teszik lehetővé és fokozzák a gyakorlatok hatását.

\section{Fejlesżöö módszerek és eszközök}

Programunkban a szociális kompetencia érzelmi tényezőinek fejlesztését céloztuk meg olyan gyakorlatokkal, amelyek segítik az érzelmek kifejezését, felismerését és szabályozását. A tréning indulása előtt kiválasztásra kerültek a kísérleti és kontrollcsoportok, majd utána felmértük a hallgatók érzelmi készségeinek fejlettségi szintjeit. Ezt követték a fejlesztő órák. A tréning alkalmain a szociális készségek fejlesztése során szokásosan használt technikákat alkalmaztuk: helyzetek, történetek dramatikus feldolgozása, modellnyújtás, szerepjáték, problémamegoldás, megerősítés. A gyakorlatokhoz a zeneterápiás eszközrendszert - hangszerek (csörgö, dob, sípok), animális hangok (sikítás, morgás, sóhaj), testhangok (taps, csettintés) - kiegészítésként használtuk. Mindezek és hitelesebb kommunikációs csatornákat eredeti végzettségét tekintve zenepedagógus és mentálhigiénés szakember. 


\section{Méröeszközök}

Az érzelmi tényezők fejlődésének mérésére egy történet alapú kérdőívet fejlesztettünk ki. A mérőeszköz alapját Halberstadt, Denham és Dunsmore (2001a, 2001b) affektív szociális kompetenciájának modellje adta. A modell alapján három fő komponenst, az érzelmi üzenetek küldését, fogadását és megtapasztalását és ezeken belül négy elemet, a tudatosítást, az azonosítást, a kontextusba helyezést és a szabályozást különböztetjük meg.

- Érzelmi üzenetek küldése: annak észlelése, mikor kell egy szituációban érzelmi üzenetet küldeni, annak átgondolása, milyen üzenetet kell vagy nem kell kommunikálni, végül az üzenet világos, tömör és szituációnak megfelelő elküldése.

- Érzelmi üzenetek fogadása: érzelmi üzenetek felénk való küldésének észlelése és ezeknek kontextusnak megfelelő interpretálása, valamint a valós és téves üzenetek megfelelő szelektálása és kezelése.

- Érzelmi üzenetek megtapasztalása: a szituációhoz kapcsolódó érzelmek észlelése, megtapasztalása és tudatosítása. Ezek után azok kontextusfüggő meghatározása és értelmezése, valamint annak eldöntése, hogy az adott érzelmi állapotot fenntartjuk, csökkentjük vagy megszakítjuk.

A kérdőív kiindulása egy időpillanatot érzékeltető helyzetkép, amely a válaszadás dinamikájának segítségével történetté fejlődik. A csoporthoz való csatlakozást érzelmi oldalról leíró történetet nyílt kérdések szakítják meg, követve a modell szerkezetét. Ezekre a hallgatók szabadon adják meg a választ, megoldva ezzel a pillanatnyilag felmerült lélektani helyzetet.

A mérőeszköz által leírt szituációval próbáltuk a hallgatókat egy általuk ismert, mindennapokban megtapasztalt környezetbe helyezni. Arra törekedtünk, hogy a történet keretét, a szereplők helyzetét és lelki állapotát minél pontosabban és objektíven írjuk körül. Ehhez alkalmaztuk az általunk használt modell elméleti hátterét.

A történet egy mindennapos, könyvtári helyzetből indul, amelyben a négy szereplő érzelmi jelzéseinek küldése, fogadása és megtapasztalása kerül megoldásra a hallgatók válaszai alapján. Három fös kis közösség együtt dolgozik egy feladaton, amelyhez a negyedik főszereplő próbál csatlakozni. Ennek a helyzetnek a dinamikáját az adja, hogy a csatlakozni kívánt szereplő kifejezi szándékát, a többiek ezt érzékelik és reagálnak rá, amit a föszereplő magában értelmez és szabályoz. A nyílt kérdésekre megadott válaszokból nyert helyzetmegoldások engednek következtetni az adott érzelmi tényező müködésére. A kipróbálás során nyert válaszokból, tipikus jegyeket kigyüjtve, válaszkategóriákat alakítottunk ki. Ezek a konvencionális, érzelmi, intellektuális és kreatív válasz. A fejlödést a kreatív válasz irányába való eltolódás jelzi, minthogy ezek a válaszok utalnak a társas helyzetek adekvát ismeretek birtokában működtetett önálló, célirányos, motiváló, alkotó és eredeti megoldására. A megnyilvánulások főbb jellegzetességei összefüggésbe hozhatóak a szociális kompetencia fejlett müködésére utaló kreatív helyzetmegoldásokkal. A válaszok besorolását két független pedagógus végezte, kizárva ezzel a fejlesztést végző pedagógus szubjektivitását az értékelés tekintetében. A bírálók mintát és példákat kaptak az értékelés módszerére vonatkozóan, és az esetleg eltérések esetében együttes megbeszélés során jutottak közös nevezőre. A 4. táblázatban példákat olvashatunk a kérdöív tételeire. 
4. táblázat. Példák a kérdöiv tételeire

\begin{tabular}{|c|c|c|}
\hline Dimenziók & Elemek & Indikátorok \\
\hline \multirow{4}{*}{$\begin{array}{l}\text { Érzelmi } \\
\text { üzenetek } \\
\text { küldése }\end{array}$} & tudatosság & István helyében hogyan kerülnél közelebb hozzájuk? \\
\hline & azonosítás & Szerinted milyen módon kéne ezt Istvánnak megtenni? \\
\hline & kontextus & $\begin{array}{l}\text { Véleményed szerint milyen további szempontjai lehetnek Istvánnak ahhoz, } \\
\text { hogy sikeresen tudjon csatlakozni? }\end{array}$ \\
\hline & szabályozás & Ha Te lennél István, hogyan jeleznél a többieknek? \\
\hline \multirow{4}{*}{$\begin{array}{l}\text { Érzelmi } \\
\text { üzenetek } \\
\text { fogadása }\end{array}$} & tudatosság & Vajon mit tesz ebben a helyzetben először István? \\
\hline & azonosítás & Mit mérlegelnél István helyében, hogy pontos legyen a helyzetértékelés? \\
\hline & kontextus & Hogyan értelmezed a többiek István felé küldött jelzéseit? \\
\hline & szabályozás & Mely mozdulatokra figyelnél oda, ha Te lennél István? \\
\hline \multirow{4}{*}{$\begin{array}{l}\text { Érzelmi } \\
\text { üzenetek } \\
\text { megtapaszta- } \\
\text { lása }\end{array}$} & tudatosság & Szerinted mi történik ebben a helyzetben Istvánnal? \\
\hline & azonosítás & Mit gondolsz, mit segíthet Istvánnak ennél a pontnál, hogy léphessen? \\
\hline & kontextus & Vajon milyen további lehetősége van Istvánnak? \\
\hline & szabályozás & $\begin{array}{l}\text { Véleményed szerint mire kell figyelnie Istvánnak a többiek jelzésének } \\
\text { értelmezésében? }\end{array}$ \\
\hline
\end{tabular}

A zenei viszonyulást vizsgáló kérdőív a Losonczy $(1964,1969)$ által kidolgozott elméleti keretből indul ki. Eszerint elkülönítettük a zenei intenzitás, a zenei aktivitás, a zenei élmény, a környező hangzásvilág érzékelése és a korábbi tréningtapasztalatok dimenzióit. A megnevezett dimenziókat elemekre bontottuk:

- A zenei intenzitás a zenéhez való viszony mennyiségét, minőségét, tudatosságát és választását foglalja magában.

- A zenei aktivitás tartalmazza a zenei tevékenységek szeretetét, módját, alkalmát, szokását és az adottság személyes megítélését.

- A zenei élmény a korábbi zenei tapasztalatok alatt szerzett élmények milyenségére és azok átélési szintjeire vonatkozik.

- A környező hangzásvilág érzékelése a hangi környezet észlelését, szeretetét, annak zavarását és az iránta mutatott közömbösséget foglalja magában.

Az 5. táblázat tartalmazza a példákat a kérdőív tételeire. A kérdőív fejlesztéséhez specifikációs táblázatot készítettünk, amelyben megjelöltük a zenei viszonyulást jelző dimenziókat, az egyes elemeket és a rájuk vonatkozó indikátorokat.

5. táblázat. Példák a kérdöiv tételeire, specifikációs táblázat a vizsgálandó zenei tényezőkre

\begin{tabular}{|l|l|l|}
\hline \multicolumn{1}{|c|}{ Dimenziók } & \multicolumn{1}{|c|}{ Elemek } & \multicolumn{1}{c|}{ Indikátorok } \\
\hline \multirow{5}{*}{ Zenei intenzitás } & szükségessége & Szükségét érzed, hogy naponta hallgass zenét? \\
\cline { 2 - 3 } & tudatossága & Zenehallgatásod véletlenszerü vagy tudatos? \\
\cline { 2 - 3 } & választása & $\begin{array}{l}\text { Hangulatod függvénye vagy napi szokásod, hogy kapcsolatba } \\
\text { legyél a zenével? }\end{array}$ \\
\cline { 2 - 4 } & hiány foka & Hiányzik-e, ha zene nélkül telik el egy napod? \\
\cline { 2 - 3 } & mennyisége & Elégségesnek tartod-e a rendelkezésre álló zenei forrásokat? \\
\hline \multirow{5}{*}{ Zenei aktivitás } & szeretete & Szeretsz-e énekelni? \\
\cline { 2 - 3 } & szokása & $\begin{array}{l}\text { Szoktál-e egyedül vagy az általad hallgatott előadóval együtt } \\
\text { énekelni? }\end{array}$ \\
\cline { 2 - 3 } & adottsága & Véleményed szerint megvan az adottságod a zenéléshez? \\
\cline { 2 - 3 } & módja & Egyedül vagy másokkal szoktál énekelni? \\
\cline { 2 - 3 } & alkalma & Az éneklést és/vagy zenélést milyen keretek között müveled? \\
\hline
\end{tabular}


Szabadi Magdolna: A szociális kompetencia érzelmi elemeinek fejlesztése zeneterápiás eszközökkel

\begin{tabular}{|l|l|l|}
\hline \multirow{4}{*}{ Zenei élmény } & kifejezése & $\begin{array}{l}\text { Érezted-e már, hogy egy zene pont azt fejezi ki, amit éppen érez- } \\
\text { tél? }\end{array}$ \\
\cline { 2 - 3 } & katarzis & Éltél-e már át katartikus élményt a zene hatására? \\
\cline { 2 - 3 } & negatív hatása & Volt-e olyan zenei tapasztalatod, ami negatív hatást váltott ki? \\
\cline { 2 - 3 } & szintjei & Zenei élményeket miként élted át? \\
\hline \multirow{4}{*}{$\begin{array}{l}\text { Környezó hangzásvi- érzékelése } \\
\text { lás }\end{array}$} & észlelése & Mely hangzások azok, amelyeket észreveszel? \\
\cline { 2 - 3 } & szeretete & Mely hangzások azok, amelyeket szeretsz? \\
\cline { 2 - 3 } & zavarása & Mely hangzások azok, amelyek zavarnak? \\
\cline { 2 - 3 } & $\begin{array}{l}\text { közömbös- } \\
\text { sége }\end{array}$ & Mely hangzások azok, amelyek közömbösek? \\
\hline \multirow{2}{*}{$\begin{array}{l}\text { Korábbi tréning } \\
\text { tapasztalatai }\end{array}$} & megléte & Vettél-e már részt az alábbi tréningfoglalkozások valamelyikén? \\
\cline { 2 - 3 } & hatása & Ha igen, hogyan hatott rád? \\
\hline
\end{tabular}

Az egyes elemekre megfogalmazott kérdésekhez válaszkategóriákat alakítottunk ki. Ezek közül a hallgatók a magukra nézve leginkább érvényeset választották ki. A kérdőív elemeinek, tételeinek és a válaszkategóriák meghatározásánál professzió-mentességre, a megfogalmazásuknál pedig a lehető legnagyobb egyszerüségre törekedtünk. (Kulcskérdésnek tekintjük, hogy vizsgálatunk ezen a téren teljes mértékben önálló gondolatokra, sajátélménybeli és gyakorlati tapasztalatokra épül, erre vonatkozó, konkrét irodalmi előzmények hiányában, jelen tudásunk szerint.) A kérdőív válaszaiból következtethetünk a hallgatók önmagukon észlelt zenei viszonyulásának minőségére. A zenei viszony elmélyülését a minőségi válaszkategóriákon tett elmozdulás mutatja a legmagasabb szintü viszonyulást leíró válaszok irányába.

\section{Az empirikus vizsgálat eredményei}

A kérdőívekkel végzett vizsgálatunk célja a tréningprogram nyomán történt fejlődés kimutatása volt az érzelmi tényezők és a zenei viszonyulás elmélyülése mentén.

\section{Az érzelmi tényezők fejlödésének eredményei}

A fejlődést az érzelmi tényezők esetében a minőségi válaszkategóriákon (konvencionális, érzelmi, intellektuális és kreatív) történt elmozdulás, konkrétan a kreatív válaszok megoszlásának százalékos arányában kimutatható növekedés jelzi. A válaszok megoszlásának százalékos emelkedését önmagukhoz mérten vizsgáltuk mind a kísérleti, mind a kontrollcsoportokban. A két csoport ekvivalensnek mondható mind a zenész, mind a reál részminta esetében, ugyanis a tréning előtti mérés azonos indulószintet mutatott a két részmintánál. Ezért a kontrollcsoport alkalmas a spontán, kísérleti beavatkozás nélküli fejlődés értékelésére.

Az érzelmi tényezők értékelésén tett kreatív válaszok megoszlásának százalékos értékeit a tréning előtt és után a zenész részminta esetében a 6 . táblázat, a reál részmintánál pedig a 7. táblázat ismerteti. Az elö- és utómérés eredményeinek összevetése szerint a kísérleti csoportokban jelentős eltérés van, magasabb fejlettséget jelez a kontrollcsoportok értékeivel szemben. Ez a tendencia mind a zenész, mind pedig a reál részminta esetében megfigyelhetö.

A zenész csoportnál a kreatív válaszok megoszlásának különbségei - tréning elött és után - százalékos értékekben kifejezve a kísérleti csoportnál 25-33,4 százalék között 
mozognak. Legnagyobb változást az érzelmi jelzések küldésének azonosításánál, az érzelmi jelzések fogadásának azonosításánál és kontextusba helyezésénél figyeltünk meg. Fontos kiemelni, hogy az érzelmi jelzések megtapasztalásának dimenziójában adott válaszokon egységesen a legmagasabb eltérést tapasztaltuk. A kontrollcsoportnál a tréning elötti és utáni különbség értékei 5,4-8,1 százalék között találhatóak. Ebben az esetben a legkevesebb eltérést az érzelmi üzenetek küldésének kontextusba helyezésénél és irányításánál, valamint az érzelmi üzenetek megtapasztalásának kontextusba helyezésénél kaptunk. A többi elem tekintetében az eltérés egységesen magasabb. A reál részmintánál a kísérleti csoport különbségeit 27,2-38,6 százalék között, a kontrollcsoportnál pedig 5,4 százalékon mutattuk ki. A kísérleti csoportnál a legnagyobb eltérést az érzelmi üzenetek küldésének kontextusba helyezésénél és az érzelmi üzenetek fogadásának azonosításánál találtuk. A kontrollcsoportnál az eltérés egységesen 5,4 százalék. Az eredmények alapján elmondható, hogy a kísérleti csoportok válaszai karakterisztikusabb eltérést mutatnak a kontrollcsoport spontán fejlődéséhez képest a tréning után. Megjegyzendő, hogy a zenész kísérleti csoport különbségei egységesebbek a reál kísérleti csoportéhoz képest. Az elő- és utóteszt eredményeinek összehasonlítására dichotomizált változókon végzett McNemar-próba szignifikancia-értékei a kísérleti csoportoknál minden elem esetében $p<0,05$, míg ugyanezen érték a kontrollcsoportok tekintetében $p>0,05$. Ezek szerint a kísérleti csoportok által adott kreatív válaszok eloszlása szignifikánsan különbözik tréning előtt és után, szemben a kontrollcsoport eredményeivel. Minthogy a bírálók ítéleteit összehasonlíthatónak tekintjük, a kérdőív kipróbálásakor folytatott értékelők közötti egyezés alapján azt mondhatjuk, hogy a kísérleti csoportok azonos indulószintről vizsgálva a tréning folyamán meghaladták a spontán fejlődést mutató kontrollcsoportokat.

Tehát az eredmények szerint a kísérleti csoportban a kreatív válaszok százalékos aránya szignifikánsan megnövekedett a tréning után, míg ez a tendencia a kontrollcsoportban nem figyelhető meg. Ez mind a zenész, mind a reál csoportok esetében kimutatható.

6. táblázat. Kreatív válaszok megoszlása százalékos értékekben kifejezve, tréning elött és után zenész részminta esetén

\begin{tabular}{|c|c|c|c|c|c|c|c|c|c|}
\hline & & \multicolumn{4}{|c|}{ Kisérleti } & \multicolumn{4}{|c|}{ Kontroll } \\
\hline $\begin{array}{l}\text { Dimen- } \\
\text { ziók }\end{array}$ & Elemek & $\begin{array}{c}\text { McNemar } \\
p\end{array}$ & Elötte & Utána & $\begin{array}{c}\text { Különb- } \\
\text { ség }\end{array}$ & $\begin{array}{c}\text { McNemar } \\
p\end{array}$ & Elötte & Utána & $\begin{array}{c}\text { Különb- } \\
\text { ség }\end{array}$ \\
\hline \multirow{4}{*}{ Küldés } & Tudatosság & 0,016 & $29,2 \%$ & $58,3 \%$ & $29,1 \%$ & 0,250 & $29,7 \%$ & $37,8 \%$ & $8,1 \%$ \\
\hline & Azonosítás & 0,008 & $20,8 \%$ & $54,2 \%$ & $33,4 \%$ & 0,250 & $21,6 \%$ & $29,7 \%$ & $8,1 \%$ \\
\hline & Kontextus & 0,016 & $33,3 \%$ & $58,3 \%$ & $25,0 \%$ & 0,500 & $32,4 \%$ & $37,8 \%$ & $5,4 \%$ \\
\hline & Irányítás & 0,031 & $37,5 \%$ & $62,5 \%$ & $25,0 \%$ & 0,500 & $37,8 \%$ & $43,2 \%$ & $5,4 \%$ \\
\hline \multirow{4}{*}{$\begin{array}{l}\text { Foga- } \\
\text { dás }\end{array}$} & Tudatosság & 0,016 & $33,3 \%$ & $62,5 \%$ & $29,2 \%$ & 0,250 & $32,4 \%$ & $40,5 \%$ & $8,1 \%$ \\
\hline & Azonosítás & 0,008 & $25,0 \%$ & $58,3 \%$ & $33,3 \%$ & 0,250 & $24,3 \%$ & $32,4 \%$ & $8,1 \%$ \\
\hline & Kontextus & 0,008 & $29,2 \%$ & $62,5 \%$ & $33,3 \%$ & 0,250 & $29,7 \%$ & $37,8 \%$ & $8,1 \%$ \\
\hline & Irányítás & 0,016 & $29,2 \%$ & $58,3 \%$ & $29,1 \%$ & 0,250 & $29,7 \%$ & $37,8 \%$ & $8,1 \%$ \\
\hline \multirow{4}{*}{$\begin{array}{l}\text { Megta- } \\
\text { paszta- } \\
\text { lás }\end{array}$} & Tudatosság & 0,008 & $25,0 \%$ & $58,3 \%$ & $33,3 \%$ & 0,250 & $24,3 \%$ & $32,4 \%$ & $8,1 \%$ \\
\hline & Azonosítás & 0,008 & $29,2 \%$ & $62,5 \%$ & $33,3 \%$ & 0,250 & $29,7 \%$ & $37,8 \%$ & $8,1 \%$ \\
\hline & Kontextus & 0,008 & $25,0 \%$ & $58,3 \%$ & $33,3 \%$ & 0,250 & $24,3 \%$ & $29,7 \%$ & $5,4 \%$ \\
\hline & Irányítás & 0,008 & $29,2 \%$ & $62,4 \%$ & $33,2 \%$ & 0,250 & $29,7 \%$ & $37,8 \%$ & $8,1 \%$ \\
\hline
\end{tabular}


Szabadi Magdolna: A szociális kompetencia érzelmi elemeinek fejlesztése zeneterápiás eszközökkel

7. táblázat. Kreatív válaszok megoszlása százalékértékekben kifejezve, tréning elött és után reál részminta esetén

\begin{tabular}{|c|c|c|c|c|c|c|c|c|c|}
\hline & & \multicolumn{4}{|c|}{ Kisérleti } & \multicolumn{4}{|c|}{ Kontroll } \\
\hline $\begin{array}{l}\text { Dimen- } \\
\text { ziók }\end{array}$ & Elemek & $\begin{array}{c}\text { McNemar } \\
p\end{array}$ & Elötte & Utána & $\begin{array}{c}\text { Különb- } \\
\text { ség }\end{array}$ & $\begin{array}{c}\text { McNemar } \\
p\end{array}$ & Elötte & Utána & $\begin{array}{c}\text { Kü- } \\
\text { lönbség }\end{array}$ \\
\hline \multirow{4}{*}{ Küldés } & Tudatosság & 0,031 & $30,1 \%$ & $59,1 \%$ & $29,0 \%$ & 0,500 & $29,7 \%$ & $35,1 \%$ & $5,4 \%$ \\
\hline & Azonosítás & 0,016 & $22,7 \%$ & $54,5 \%$ & $31,8 \%$ & 0,500 & $21,6 \%$ & $27,0 \%$ & $5,4 \%$ \\
\hline & Kontextus & 0,008 & $31,8 \%$ & $68,2 \%$ & $36,4 \%$ & 0,500 & $32,4 \%$ & $37,8 \%$ & $5,4 \%$ \\
\hline & Irányítás & 0,016 & $36,4 \%$ & $68,2 \%$ & $31,8 \%$ & 0,500 & $37,8 \%$ & $43,2 \%$ & $5,4 \%$ \\
\hline \multirow{4}{*}{ Fogadás } & Tudatosság & 0,016 & $31,8 \%$ & $63,6 \%$ & $31,8 \%$ & 0,500 & $32,4 \%$ & $37,8 \%$ & $5,4 \%$ \\
\hline & Azonosítás & 0,008 & $25,0 \%$ & $63,6 \%$ & $38,6 \%$ & 0,500 & $24,3 \%$ & $29,7 \%$ & $5,4 \%$ \\
\hline & Kontextus & 0,016 & $27,3 \%$ & $59,1 \%$ & $31,8 \%$ & 0,500 & $27,0 \%$ & $32,4 \%$ & $5,4 \%$ \\
\hline & Irányítás & 0,016 & $27,3 \%$ & $59,1 \%$ & $31,8 \%$ & 0,500 & $27,0 \%$ & $32,4 \%$ & $5,4 \%$ \\
\hline \multirow{4}{*}{$\begin{array}{l}\text { Megta- } \\
\text { pasztalás }\end{array}$} & Tudatosság & 0,031 & $27,3 \%$ & $54,5 \%$ & $27,2 \%$ & 0,500 & $27,0 \%$ & $32,4 \%$ & $5,4 \%$ \\
\hline & Azonosítás & 0,016 & $27,3 \%$ & $59,1 \%$ & $31,8 \%$ & 0,500 & $27,0 \%$ & $32,4 \%$ & $5,4 \%$ \\
\hline & Kontextus & 0,016 & $25,0 \%$ & $59,1 \%$ & $34,1 \%$ & 0,500 & $24,3 \%$ & $29,7 \%$ & $5,4 \%$ \\
\hline & Irányítás & 0,031 & $30,8 \%$ & $59,1 \%$ & $28,3 \%$ & 0,500 & $29,7 \%$ & $35,1 \%$ & $5,4 \%$ \\
\hline
\end{tabular}

Az érzelmi elemeket mérő kérdőív belső validitását kontrollkérdésekkel ellenőriztük. Ez azt jelentette, hogy az egyes elemek (tudatosság, azonosítás, kontextus és irányítás) után az eredeti kérdéseket más megfogalmazásban tettük fel. A kontrollkérdéseket a dimenziók (érzelmi üzenetek küldése, fogadása és megtapasztalása) után helyeztük el. A fö- és kontrollkérdések összefüggéseinek szignifikanciáját és egyezésük mértékét a 8. táblázatban foglaltuk össze.

Az eredmények alapján elmondhatjuk, a kérdések közti összefüggés minden elem tekintetében $\mathrm{p}<0,001$ szinten szignifikáns, és az egyezésük mértékét jelző Cronbach- $\kappa$ mutató 0,8 feletti értékei is rendkívül magas együtt járást mutatnak. A legszorosabb összefüggést az érzelmi üzenetek küldésének tudatosságában mutattunk ki, míg a leggyengébbet az érzelmi üzenetek fogadásának kontextusba helyezésénél találtunk. Eszerint az érzelmi jelzések kifejezésének tudatosságára vonatkozó fő és kontrollkérdéseket itélték leginkább hasonlóan a bírálók, míg az érzelmi jelzések kontextus szerinti értelmezése a legkülönbözőbb megítélés alá esett. Az eredmények szerint az érzelmi tényezők belső validitása nagyon jónak mondható.

8. táblázat. Belső validitás az érzelmi elemeken ( $\chi^{2}$, Cronbach- $\left.\kappa\right)$

\begin{tabular}{|l|c|c|c|c|c|c|c|c|c|}
\hline & \multicolumn{4}{|c|}{ Küldés } & \multicolumn{3}{c|}{ Fogadás } & \multicolumn{3}{c|}{ Megtapasztalás } \\
\hline Elemek & $\chi^{2}$ & $p$ & Crombach- $\kappa$ & $\chi^{2}$ & $p$ & Cronbach- $\kappa$ & $\chi^{2}$ & $p$ & Cronbach- $\kappa$ \\
\hline Tudatosság & 98,2 & 0,000 & 0,903 & 92,9 &, 000 & 0,873 & 93,7 & 0,000 & 0,877 \\
\hline Azonosítás & 87,5 & 0,000 & 0,843 & 97,1 &, 000 & 0,895 & 94,8 & 0,000 & 0,883 \\
\hline Kontextus & 96,2 & 0,000 & 0,890 & 94,8 &, 000 & 0,883 & 93,3 & 0,000 & 0,875 \\
\hline Irányítás & 94,1 & 0,000 & 0,879 & 91,4 &, 000 & 0,865 & 95,5 & 0,000 & 0,886 \\
\hline
\end{tabular}




\section{A zenei viszonyulás változásának eredményei}

A zenei viszonyulást vizsgáló kérdőív tekintetében a fejlődést a legelmélyültebb viszonyt mutató válaszkategóriák százalékos arányában bekövetkező emelkedés érzékelteti. A legelmélyültebb zenei viszonyt jelző minőségi válaszok eloszlásának százalékos értékeit pedig a zenész részminta esetében a 9. táblázat, a reál részminta esetében pedig a 10. táblázat ismerteti. Az elő- és utómérés eredményeinek összehasonlítása alapján a kísérleti csoportban jelentős eltérés van, mert nagyobb fejlődést jelez a kontrollcsoport értékeivel szemben. Ez a tendencia mind a zenész, mind pedig a reál részminta esetében megfigyelhető.

A zenész csoportnál a legelmélyültebb zenei viszonyulásra utaló válaszok tréning előtt és után megfigyelt különbségei százalékos értékekben kifejezve a kísérleti csoportnál 12,5-20,8 százalék között találhatóak. A legnagyobb eltérést a környező hangzásvilág észlelésénél, szereteténél és közömbösségénél figyeltünk meg. A kontrollcsoportnál ezen értékek 2,7-8,1 százalék között figyelhetőek meg. A legnagyobb különbség ugyancsak a környező hangzásvilág észlelésénél, szereteténél és a zenei aktivitás alkalmánál található. A reál részminta esetében a kísérleti csoport különbségei 9,1-18 százalék között találhatóak, a kontrollcsoportnál pedig 2,7-5,4 százalék között. A legnagyobb változást a kísérleti csoportnál szintén a környező hangzásvilág észlelésénél, szereteténél mutattunk ki, míg a kontrollcsoportnál a zenész részmintához hasonlóan a környező hangzásvilág észlelésénél, szereteténél és a zenei aktivitás alkalmánál. Az adatok azt mutatják, hogy a direkt fejlesztés és spontán fejlődés is leginkább a környező hangzásvilághoz való viszonyt érintette leginkább. Az elö- és utóteszt eredményeinek összehasonlítására dichotomizált változókkal végzett $\mathrm{McNemar-próba} \mathrm{szignifikancia-értékei} \mathrm{a} \mathrm{kísérleti} \mathrm{cso-}$ portoknál minden elem esetében $p<0,05$. Ez az érték a kontrollcsoportok tekintetében $\mathrm{p}>0,05$. Ezek szerint a kísérleti csoportok válaszainak eloszlása szignifikánsan különbözik tréning elött és után, ellentétben a kontrollcsoport eredményeivel. Tehát a kísérleti csoportok válaszai karakterisztikus és szignifikáns eltérést mutatnak a tréning után, szemben a kontrollcsoportokkal.

Ezek alapján a kísérleti csoportban a legelmélyültebb zenei válaszok százalékos aránya szignifikánsan megnövekedett a tréning után, míg ez az irány a kontrollcsoportban nem figyelhető meg. Ez érvényes mind a zenész, mind a reál csoportokra.

9. táblázat. A legelmélyültebb zenei viszonyulást jelzö válaszok megoszlásának százalékos értékei, tréning elött és után zenész részminta esetén

\begin{tabular}{|c|c|c|c|c|c|c|c|c|c|}
\hline \multirow[b]{2}{*}{$\begin{array}{l}\text { Dimen- } \\
\text { ziók }\end{array}$} & \multirow[b]{2}{*}{ Elemek } & \multicolumn{4}{|c|}{ Kisérleti } & \multicolumn{4}{|c|}{ Kontroll } \\
\hline & & $\begin{array}{c}\text { McNemar } \\
p\end{array}$ & Elötte & Utána & $\begin{array}{c}\text { Különb- } \\
\text { ség }\end{array}$ & $\begin{array}{c}\text { McNemar } \\
p\end{array}$ & Elötte & Utána & $\begin{array}{c}\text { Különb- } \\
\text { ség }\end{array}$ \\
\hline \multirow{5}{*}{$\begin{array}{l}\text { Intenzi- } \\
\text { tás }\end{array}$} & Szükségessége & 0,000 & 75,0 & 91,7 & $16,7 \%$ & 0,500 & 75,7 & 78,4 & $2,7 \%$ \\
\hline & Tudatossága & 0,004 & 79,2 & 91,7 & $12,5 \%$ & 0,500 & 78,4 & 81,1 & $2,7 \%$ \\
\hline & Választása & 0,004 & 79,2 & 91,7 & $12, \%$ & 0,500 & 78,4 & 83,8 & $5,4 \%$ \\
\hline & Hiány foka & 0,004 & 70,8 & 87,5 & $16,7 \%$ & 0,500 & 70,3 & 75,7 & $5,4 \%$ \\
\hline & Mennyisége & 0,004 & 29,2 & 12,5 & $16,7 \%$ & 0,500 & 29,7 & 24,3 & $5,4 \%$ \\
\hline \multirow{5}{*}{$\begin{array}{l}\text { Aktivi- } \\
\text { tás }\end{array}$} & Szeretete & 0,004 & 75,0 & 87,5 & $12,5 \%$ & 1,000 & 75,7 & 78,4 & $2,7 \%$ \\
\hline & Szokása & 0,004 & 70,8 & 87,5 & $16,7 \%$ & 1,000 & 70,3 & 73,0 & $2,7 \%$ \\
\hline & Tudása & 0,011 & 75,0 & 91,7 & $16,7 \%$ & 1,000 & 75,7 & 78,4 & $2,7 \%$ \\
\hline & Módja & 0,000 & 70,8 & 87,6 & $16,8 \%$ & 1,000 & 70,3 & 75,7 & $5,4 \%$ \\
\hline & Alkalma & 0,010 & 70,8 & 87,5 & $16,7 \%$ & 0,200 & 70,3 & 78,4 & $8,1 \%$ \\
\hline
\end{tabular}


Szabadi Magdolna: A szociális kompetencia érzelmi elemeinek fejlesztése zeneterápiás eszközökkel

\begin{tabular}{|c|c|c|c|c|c|c|c|c|c|}
\hline & & \multicolumn{4}{|c|}{ Kisérleti } & \multicolumn{4}{|c|}{ Kontroll } \\
\hline $\begin{array}{l}\text { Dimen- } \\
\text { ziók }\end{array}$ & Elemek & $\begin{array}{c}\text { McNemar } \\
p\end{array}$ & Elötte & Utána & $\begin{array}{c}\text { Különb- } \\
\text { ség }\end{array}$ & $\begin{array}{c}\text { McNemar } \\
p\end{array}$ & Elötte & Utána & $\begin{array}{c}\text { Különb- } \\
\text { ség }\end{array}$ \\
\hline \multirow{4}{*}{$\begin{array}{l}\text { Zenei } \\
\text { élmény }\end{array}$} & Kifejezése & 0,011 & 75,0 & 91,7 & $16,7 \%$ & 0,500 & 75,7 & 81,7 & $6,0 \%$ \\
\hline & Negatív hatása & 0,012 & 83,3 & 95,8 & $12,5 \%$ & 1,000 & 83,8 & 86,7 & $2,9 \%$ \\
\hline & Katarzis & 0,011 & 75,0 & 95,8 & $20,8 \%$ & 0,700 & 75,7 & 81,1 & $5,4 \%$ \\
\hline & Szintjei & 0,011 & 75,0 & 91,7 & $16,7 \%$ & 0,500 & 75,7 & 81,1 & $5,4 \%$ \\
\hline \multirow{4}{*}{$\begin{array}{l}\text { Kör- } \\
\text { nyezö } \\
\text { hang- } \\
\text { zásvilág }\end{array}$} & Észlelése & 0,004 & 70,8 & 91,7 & $20,9 \%$ & 0,200 & 70,3 & 78,4 & $8,1 \%$ \\
\hline & Szeretete & 0,004 & 70,8 & 91,7 & $20,9 \%$ & 0,200 & 70,3 & 78,4 & $8,1 \%$ \\
\hline & Zavarása & 0,004 & 70,8 & 87,5 & $16,7 \%$ & 0,500 & 70,3 & 75,7 & $5,4 \%$ \\
\hline & Közömbössége & 0,004 & 70,8 & 91,7 & $20,9 \%$ & 0,500 & 70,3 & 75,7 & $5,4 \%$ \\
\hline
\end{tabular}

10. táblázat. Legelmélyültebb zenei viszonyulást jelzö válaszok eloszlásának százalékos értékei, tréning elött és után reál részminta esetén

\begin{tabular}{|c|c|c|c|c|c|c|c|c|c|}
\hline \multirow[b]{2}{*}{ Dimenziók } & \multirow[b]{2}{*}{ Elemek } & \multicolumn{4}{|c|}{ Kisérleti } & \multicolumn{4}{|c|}{ Kontroll } \\
\hline & & $\begin{array}{c}\text { McNemar } \\
p\end{array}$ & $\begin{array}{c}\text { Elöt- } \\
\text { te }\end{array}$ & $\begin{array}{l}\text { Utá- } \\
n a\end{array}$ & $\begin{array}{c}\text { Különb- } \\
\text { ség }\end{array}$ & $\begin{array}{c}\text { McNemar } \\
p\end{array}$ & $\begin{array}{c}\text { Elöt- } \\
\text { te }\end{array}$ & $\begin{array}{c}\text { Utá- } \\
n a\end{array}$ & $\begin{array}{c}\text { Különb } \\
\text { ség }\end{array}$ \\
\hline \multirow{5}{*}{ Intenzitás } & $\begin{array}{l}\text { Szükséges- } \\
\text { sége }\end{array}$ & 0,002 & 72,7 & 86,7 & $14,0 \%$ & 0,500 & 75,7 & 78,4 & $2,7 \%$ \\
\hline & Tudatossága & 0,006 & 77,3 & 90,9 & $13,6 \%$ & 1,000 & 78,4 & 81,1 & $2,7 \%$ \\
\hline & Választása & 0,006 & 77,3 & 90,9 & $13,6 \%$ & 0,700 & 78,4 & 83,8 & $5,4 \%$ \\
\hline & Hiány foka & 0,002 & 72,7 & 86,4 & $13,7 \%$ & 0,500 & 70,3 & 75,7 & $5,4 \%$ \\
\hline & Mennyisége & 0,002 & 27,3 & 13,6 & $13,7 \%$ & 0,500 & 29,7 & 24,3 & $5,4 \%$ \\
\hline \multirow{5}{*}{ Aktivitás } & Szeretete & 0,002 & 72,7 & 86,4 & $13,6 \%$ & 0,500 & 75,7 & 78,4 & $2,7 \%$ \\
\hline & Szokása & 0,001 & 68,7 & 81,8 & $13,1 \%$ & 0,500 & 70,3 & 73,0 & $2,7 \%$ \\
\hline & Tudása & 0,002 & 72,7 & 86,4 & $13,7 \%$ & 1,000 & 75,7 & 78,4 & $2,7 \%$ \\
\hline & Módja & 0,000 & 72,7 & 86,4 & $13,7 \%$ & 1,000 & 70,3 & 75,7 & $5,4 \%$ \\
\hline & Alkalma & 0,000 & 72,7 & 86,4 & $13,7 \%$ & 0,500 & 70,3 & 78,4 & $8,1 \%$ \\
\hline \multirow{4}{*}{$\begin{array}{l}\text { Zenei } \\
\text { élmény }\end{array}$} & Kifejezése & 0,002 & 72,7 & 86,4 & $13,7 \%$ & 0,500 & 75,7 & 81,7 & $6,0 \%$ \\
\hline & $\begin{array}{l}\text { Negatív } \\
\text { hatása }\end{array}$ & 0,010 & 86,4 & 95,5 & $9,1 \%$ & 0,625 & 83,8 & 86,7 & $2,9 \%$ \\
\hline & Katarzis & 0,010 & 77,5 & 95,5 & $18,0 \%$ & 0,500 & 75,7 & 81,1 & $5,4 \%$ \\
\hline & Szintjei & 0,002 & 72,7 & 86,4 & $13,7 \%$ & 0,500 & 75,7 & 81,1 & $5,4 \%$ \\
\hline \multirow{4}{*}{$\begin{array}{l}\text { Környezö } \\
\text { hangzás- } \\
\text { világ }\end{array}$} & Észlelése & 0,000 & 68,2 & 86,4 & $18,2 \%$ & 0,157 & 70,3 & 78,4 & $8,1 \%$ \\
\hline & Szeretete & 0,000 & 68,2 & 86,4 & $18,2 \%$ & 0,157 & 70,3 & 78,4 & $8,1 \%$ \\
\hline & Zavarása & 0,002 & 72,7 & 86,4 & 13,7 & 0,500 & 70,3 & 75,7 & $5,4 \%$ \\
\hline & $\begin{array}{l}\text { Közömbös- } \\
\text { sége }\end{array}$ & 0,002 & 72,7 & 86,4 & $13,7 \%$ & 0,500 & 70,3 & 75,7 & $5,4 \%$ \\
\hline
\end{tabular}

\section{Összegzés}

Tanulmányunk egy fejlesztő program eredményeit mutatja be, amely a pedagógusképzésben részt vevő hallgatók számára készült, célja pedig a szociális kompetencia érzelmi elemeinek fejlesztése volt. A fejlesztő gyakorlatok szociális készségeket fejlesztő technikákat vettek alapul, melyeket zeneterápiás eszközökkel egészítettünk ki. A tréning alatt a hallgatók saját élményben tapasztalták meg a gyakorlatok hatását, így 
módszertani eszköztáruk bővítésével sikerrel tudják azokat később osztálykeretben alkalmazni.

Az érzelmi elemek fejlődésének mérésére saját fejlesztésű kérdőívet készítettünk. Az eszköz az Affektív- szociális kompetencia modelljére épül, és egy csoporthoz való csatlakozás történetét mutatja be. A fejlődést az előre kialakított válaszkategóriákon (konvencionális, intellektuális, érzelmi és kreatív) történő kreativitás irányába való elmozdulás jelzi.

Az eredményekből megállapítható, hogy a hallgatók tréning után adott kreatív válaszainak megoszlásában a kísérleti csoportok esetén, önmagukhoz mérten 25-38 százalékos növekedés mutatható ki, míg ezek az értékek a kontrollcsoportoknál 5,4-8,1 százalék között találhatóak. A tréning előtti és utáni kreatív válaszok megoszlásának összehasonlítását jelző McNemar-próba p értékei a kísérleti csoportoknál szignifikáns különbséget jeleznek a kontrollcsoporttal szemben. A kísérleti csoportok pozitív elmozdulást jeleznek a kontrollcsoportokhoz képest. A fejlődés mértéke nem függött a specializációtól, azaz attól, hogy a résztvevő a zenész vagy a reál csoportba tartozott. Kijelenthető, hogy a kísérleti csoportok mutatói jóval túlhaladják a kontrollcsoportok spontán fejlődését. Az eredmények megerősítették, hogy a hallgatók szociális kompetenciájának érzelmi tényezői a felsőoktatás keretei között fejleszthetőek. A program eredményei alapján elmondható, hogy a felsőoktatásban végzett direkt fejlesztés a hallgatók nagy hányadánál az érzelmi készségek fejlesztését eredményezte

A program közvetett hatásaként a zenei viszony elmélyülését is vártuk. Az e területen bekövetkezett fejlődést a legelmélyültebb zenei viszonyulást jelző válaszok megoszlásának százalékos növekedése mutatta. A kísérleti csoportokban 12-18 százalékos különbséget tapasztaltunk a hallgatók legelmélyültebb válaszainak megoszlása között tréning előtt és után. A kontrollcsoportok különbségei 2,7-8,1 százalék között találhatóak. A tréning elötti és utáni válaszok megoszlásának összehasonlítását mutató McNemar-próba p értékei a kísérleti csoportoknál szignifikáns különbséget jeleznek, ellentétben a kontrollcsoporttal. A kísérleti csoportok jelentős fejlődést mutatnak a kontrollcsoportokhoz viszonyítva.

A program egyben felhívja a figyelmet Zsolnai és Józsa (2003) alapján az érzelmi tényezők módszertani nehézségeire. A fejlettség megítélésére alkalmas lehet a hallgatókat ismerö pedagógus, azonban a bírálat szubjektivitása, mint minden ilyen esetben, rendkívül erősen megjelenik. Az érzelmi tényezők fejlettségének megbízhatósága a bírálók számának növelésével lehetséges. Ez azonban az értékelési folyamat bonyolultsága és időigényessége miatt rendkívül nehézkes. Továbbá a két csoport összehasonlítása helyett a készségek önmagukhoz mért fejlődését szükséges vizsgálni.

A szubjektivitás csökkentésére és a megbízhatóság növelésére az alábbi lehetőségeink voltak: az értékelési rendszer pontos meghatározása, a független bírálók számának életterünknek megfelelően a lehető legnagyobb mértékű megnövelése, és egyezésük mértékének kiváló szintü kimutatása a kérdőív kipróbálásának folyamatában, valamint a fejlesztést végző pedagógus és terapeuta értékelési folyamatból való kimaradása és a fejlesztett hallgatóktól való függetlenségének biztosítása.

Fejlesztő kísérletünk első állomása lehet egy kísérletsorozatnak. További, hosszabb távú fejlesztő programsorozat kialakítására van szükség azért, hogy feltárjuk azokat az egyéb lehetőségeket, módszereket és eszközöket, melyekkel az érzelmi tényezők további szinteken és életkorban fejleszthetőek és minél pontosabban mérhetőek. 


\section{Irodalomjegyzék}

Blair, K. A., Denham, S. A., Kochanoff, A. és Whipple, B. (2004): Playing it cool: Temperament, emotion regulation and social behavior in preschoolers. Journal of School Psychology, 42. 6. sz. 419-443. DOI: 10.1016/j.jsp.2004.10.002

Cheung, Ch. és Lee, T. (2010): Improving social competence through character education. Evaluation and Program Planning, 33. 3. sz. 255-263. DOI: 10.1016/j.evalprogplan.2009.08.006

Denham, S. A. és Burton, B. (1996): A socialemotional intervention for at-risk 4-year-olds. Journal of School Psychology, 34. 3. sz. 225-245. DOI: 10.1016/0022-4405(96)00013-1

Denham, S. A., Blair, K. A., DeMulder, E., Levitas, J., Sawyer, K., Auerbach-Major, S. és Queenan, S. (2003): Preschool Emotional Competence: Pathway to Social Competence? Child Development, 74. 1. sz. 238-256. DOI: 10.1111/1467-8624.00533

Gerevich József (1987, szerk.): Közösségi mentálhigiéné. Animula Kiadó, Budapest.

Greca, A. M. és Santogrossi, D. A. (1980): Social skills training with elementary school students: A behavioral group approach. Journal of Consulting and Clinical Psychology, 48. 2. sz. 220-227. DOI: 10.1037/0022-006x.48.2.220

Gross, J. J. (2002): Emotional regulation: Affective, cognitive and social consequences. Psychophysiology, 39.3. sz. 281-291. DOI: 10.1017/s0048577201393198

Halberstadt, A. G., Denham, S. A. és Dunsmore, J. C. (2001a): Affective Social Competence. Social Development, 10. 1. sz. 79-119. DOI: 10.1111/14679507.00150

Halberstadt, A. G., Denham, S. A. és Dunsmore, J. C. (2001b): Spinning the Pinwheel, Together: More thoughts on Affective Social Competence. Social Development, 10. 1. sz. 130-136. DOI: 10.1111/14679507.00153

Han, H. S. és Kemple, M. (2006): Components of Social Competence and Strategies Support: Considering What to Teach and How. Early Childhood Education Journal, 34. 3. 241-247. DOI: 10.1007/ s10643-006-0139-2

Kasik László (2007): A szociális kompetencia fejlesztésének elmélete és gyakorlata. Iskolakultúra, 17. 11-12. sz. 21-37.

Konta Ildikó (2010): Személyiség és szociáliskészség-fejlesztés zeneterápiás eszközökkel az általános iskolában. In: Zsolnai Anikó és Kasik László (szerk.): A szociális kompetencia fejlesztésének elméleti és gyakorlati alapjai. Nemzeti Tankönyvkiadó, Budapest. 233-247.

Konta Ildikó és Zsolnai Anikó (2002): A szociális készségek játékos fejlesztése az iskolában. Nemzeti Tankönyvkiadó, Budapest.

Losonczy Ágnes (1964): Egy zeneszociológiai kutatásról. Magyar Zene, 4. 3. sz. 57-66.

Losonczy Ágnes (1969): A zene életének szociológiája. Zenemükiadó, Budapest.

Nemzeti alaptanterv 2012. (2012) Oktatási Minisztérium, Budapest.

Parbery-Clark, A., Skoe, E. és Kraus, N. (2009): Musical Experience Limits the Degradative Effects of Background Noise on the Neural Processing of Sound. The Journal of Neurosciences, 29. 45. sz. 14 100-14 107.DOI: 10.1523/jneurosci.3256-09.2009

Saarni (1999): The development of emotional competence. Guildford Press, New York.

Saarni (2001): Cognition, Context, and Goals: Significant Components in Social-Emotional Effectiveness. Social Development, 10. 1. sz. 125129. DOI: $10.1111 / 1467-9507.00152$

Seeman, T. E., Kaplan, G. A., Knudsen, L., Cohen, R. és Guralnik, J. (1987): Social network ties and mortality among the elderly in the Alameda County Study. American Journal of Epidemiology, 126. 4. sz. 714-723.

Shahin, A., Roberts, L. E. és Trainor, L. J. (2004): Enchancement of auditory cortical development by musical experience in children. Neuroreport, 15. 12. sz. 1917-1921. DOI: 10.1097/00001756-20040826000017

Vértes László (2010): Gerorehabilitációban alkalmazott zeneterápia. Rehabilitáció, 20. 4. sz. 90-95.

Wong, P. C. M., Skoe, E., Russo, N. M., Dees, T. és Kraus, N. (2007): Musical experience shapes human brainstem encoding of linguistic pitch patterns. Nature Neurosciences, 10. 4. sz. 420-422. DOI: $10.1038 / \mathrm{nn} 1872$

Zsolnai Anikó és Józsa Krisztián (2003): A szociális készségek fejlesztése kisiskolás korban. In: Zsolnai Anikó (szerk.): Szociális kompetencia - társas viselkedés. Gondolat Kiadó, Budapest. 227-238.

Zsolnai Anikó (2010): A szociális kompetencia kutatására és fejlesztésére szolgáló modellek. In: Zsolnai Anikó és Kasik László (szerk.): A szociális kompetencia fejlesztésének elméleti és gyakorlati alapjai. Nemzeti Tankönyvkiadó, Budapest. 78-96. 